\title{
A Political Scientist Among the Anthropologists ${ }^{1}$
}

One of the central questions driving my research as a political scientist is understanding why ethnic conflict in multi-ethnic states revolves around one identity rather than another. Why, for example, do some regions of a diverse polity like India experience recurrent religious conflict whereas other regions experience severe caste conflict? In my book, The Colonial Origins of Ethnic Violence in India, ${ }^{2}$ I argue that these patterns of conflict are shaped by the legacies of British rule, especially the enduring divide between directly ruled provinces and indirectly ruled princely states. I contend that British administrators, in the wake of the 1857 Rebellion that they interpreted as a religious (Muslim) uprising, began to emphasize caste and tribal identities in their provincial governments, creating policies of ethnic stratification that led to increased caste and tribal conflict over the long run. Princely rulers, on the other hand, did the opposite: they implemented ethnic policies on the basis of religion, thereby creating legacies of communal violence. I defend this argument using archival research and interviews carried out in four comparative case studies (comparing two sets of contiguous provinces and princely states in Rajasthan and Kerala), one additional case study, and a statistical analysis of ethnic violence across 589 Indian districts.

This is, of course, a revisionist thesis. I believe, for example, that British rule may have minimized rather than exacerbated religious conflict. In anticipation of counterarguments, I studied the case that most seriously challenged my theory-the princely state of Bastar in central-eastern India. This princely kingdom was a major centre of tribal unrest during the colonial period, and today it is the epicentre of Maoist (largely tribal) conflict. My article in Modern Asian Studies

\footnotetext{
${ }^{1}$ The title is a play on Cohn, B. (1988). An Anthropologist among the Historians and Other Essays, Oxford University Press, Oxford.

${ }^{2}$ Verghese, A. (2016). The Colonial Origins of Ethnic Violence in India, Stanford University Press, Stanford.
} 
(hereafter $M A S$ ) in 2016 attempted to explain this puzzle, ${ }^{3}$ and the argument was expanded upon in Chapter 4 of my book.

Dr Nandini Sundar, a scholar whose work and persistent activism on behalf of tribal communities I admire, has written a letter to the editors of $M A S$ critiquing my analysis of the Bastar case ${ }^{4}$. She details four major criticisms: 1) that my article is derivative of her work, 2) that I do not cite her work adequately, 3) that one cannot fruitfully compare provinces and princely states, and 4) that the colonial experience is unrelated to Naxal violence. I deal with each of these criticisms in turn in this response.

Dr Sundar's first critique deals with the fact that my article addresses themes that are similar to those of her book, Subalterns and Sovereigns: An Anthropological History of Bastar (I 854-1996) (hereafter SES). ${ }^{5}$ I opened this response with a brief review of my book to explain how Dr Sundar and I ended up studying the same region of India while approaching it from different disciplinary backgrounds, and for very different reasons. In fact, more than a third of my article in $M A S$ is not directly about Bastar but instead deals with the scholarly literature on British direct rule in India, indirect rule in the princely states, the growth of tribal rebellion during colonialism, and, subsequently, Naxalism in post-colonial India. None of these topics is central to $S \mathscr{E} S$. The title of my article should make this difference clear-I am using Bastar as a case study to tackle the broader issue of British colonialism in India and its effect on tribal violence. Bastar is a 'deviant case'it does not fit the theory that British rule generated tribal rebellion and Naxalism, and therefore must be explained. This approach is significantly different from providing an 'anthropological history' of Bastar, the subject of Dr Sundar's work, which also relies on a variety of methodologies—oral histories, ethnographic fieldwork, the symbolic interpretation of religious festivals, etc.- that are not common in political science.

Dr Sundar's second critique is that I did not cite her enough. In fact, I cite Dr Sundar's work—not just $S E S$, but also an article she published

\footnotetext{
${ }^{3}$ Verghese, A. (2016). British Rule and Tribal Revolts in India: The curious case of Bastar, Modern Asian Studies 50:5, pp. 1619-1644, doi: $10.1017 /$ Soo26749X1400o687.

${ }^{4}$ Sundar, N. (2017). Letter to the Editors, Modern Asian Studies 51:4, pp. 1220-1221, doi: 10.1017 /Soo26749X17000683.

${ }^{5}$ Sundar, N. (2007). Subalterns and Sovereigns: An Anthropological History of Bastar (I854-1996), $2^{\text {nd }}$ edition, Oxford University Press, Oxford.
} 
in the Journal of the Royal Anthropological Institute in $2001^{6}$ —eight times in my article. No author is cited more than Dr Sundar. I think that I have accurately and appropriately framed the ways in which my research is indebted to hers, at times confirming some of her findings and at other times challenging them, but always analysing them within a broader macro-historical context. For Dr Sundar to claim that my work is simply a 'term paper summary' of themes in her book is a dismissive and cursory critique that does not take seriously the ways in which my work is different from hers and contributes to the debates surrounding colonialism and ethnic violence. For example, whereas Dr Sundar argues at length that Bastar was not disconnected from the broader currents of Indian history, I argue that, due to its geographical attributes, Bastar was a remote outpost in India. Second, Dr Sundar and I have very different interpretations of the 1910 rebellion in Bastar (the bhumkal). She writes that, 'In any event, the British heavily discounted the possibility that any of their own policies could have been responsible for the [1910] rebellion... Palace intrigue, in short, was the crux of the administrative explanation for the rebellion...,7 In contrast, my article argues that the British openly blamed their own policies for the rebellion. The chief commissioner of the Central Provinces noted in a report at the time: 'from an examination of the evidence before them the Government of India were of opinion that a too zealous forest administration might not improbably be the main cause of the discontent of the hill-tribes'. ${ }^{8}$ I present several additional archival documents stressing this fact, documents which, to my knowledge, were not cited in $S \mathcal{E} S$. This work-'some archival research' as Dr Sundar casually described it—included a total of four months working across the British Library in London, the Deshbandhu Press Library in Raipur, and the National Archives of India in New Delhi. I see my article as building productively on Dr Sundar's work while using a different disciplinary approach and addressing different questions.

The final two arguments that Dr Sundar makes are more interesting. She contends that comparing provinces and princely states in India is deeply problematic, and that variations in colonial rule have little to do with the growth of Naxalism in India.

\footnotetext{
${ }^{6}$ Sundar, N. (2001). Debating Dussehra and Reinterpreting Rebellion in Bastar District, Central India, The Journal of the Royal Anthropological Institute 7:1, pp. 19-35.

${ }^{7}$ Sundar, Subalterns and Sovereigns, p. 150.

${ }^{8}$ Verghese, British Rule and Tribal Revolts in India, p. 1632.
} 
On the first point, Dr Sundar writes: 'The difference between princely states and British India is a complicated one, mediated by the way in which indirect rule was practiced, and not a simple axis along which one can write "compare and contrast" essays.' This must be a surprising statement to the many fine scholars who have compared provinces and princely states, a literature that goes back at least $5^{0}$ years. Lloyd and Susanne Rudolph compared direct and indirect rule in Rajputana. ${ }^{9}$ John Hurd II compared developmental legacies across a wide swath of provinces and princely states. ${ }^{10}$ John Wood studied British and princely legacies in Gujarat. ${ }^{11}$ And Karen Leonard, in a piece published in $M A S$, argued that: 'Indirect rule and the so-called princely or native states of India provide opportunities for comparative investigation of modern South Asian cultural configurations. ${ }^{12}$ Furthermore, I work within a subfield of American political science called Comparative Politics, so comparing and contrasting different political administrations is fundamental to the work I do and that I train my students to do. It is odd for Dr Sundar to suggest that a comparativist stop comparing.

It seems to me that the crux of her claim here is that Bastar is 'scarcely unique' (with respect to British intervention and land and forest policies), and, therefore, comparing provinces and princely states is fruitless. This is not true, even if Bastar is only compared to surrounding princely states. Consider the following, which I elaborate upon in my book: ${ }^{13}$ Bastar received no gun salute from the British, which was a ceremonial distinction that marked the prestige of princely rulers and their states. However, four smaller states in the region-Mayurbhanj, Patna, Kalahandi, and Sonpur-received ninegun salutes. And the raja of Bastar applied for a nine-gun salute but was denied. Why was this kingdom treated differently? Moreover, there is no princely state in India that has the per capita Maoist violence of contemporary Bastar. This small region of two million people accounts for more than 40 per cent of Naxalite violence in

\footnotetext{
${ }^{9}$ Rudolph, L.I., and Rudolph, S.H. (1966). Rajputana under British Paramountcy: The Failure of Indirect Rule, The Journal of Modern History 38:2, pp. 138-16o.

${ }^{10}$ Hurd II, J. (1975). The Economic Consequences of Indirect Rule in India, The Indian Economic and Social History Review 12:2, pp. 169-181.

${ }^{11}$ Wood, J.R. (1984). British versus Princely Legacies and the Political Integration of Gujarat, Journal of Asian Studies 44:1, pp. 65-99.

${ }^{12}$ Leonard, K. (2003). Reassessing Indirect Rule in Hyderabad: Rule, Ruler, or Sons-in-Law of the State?, Modern Asian Studies 37:2, pp. 363-379.

${ }^{13}$ Verghese, The Colonial Origins, p. 153.
} 
India today. If none of this qualifies Bastar to be considered 'unique', then I am not sure what would.

On the second point, Dr Sundar writes: 'The spread of the Maoist movement today also has little to do with princely India vs. British India and more to do with a host of other factors like the nature of socio-economic stratification, Maoist strategy (including proximity to its early centres), the form that social movements have taken, regime responses, and so on.' She suggests, in other words, that there are other factors more important than the distinction between direct and indirect rule. This can be tested empirically. In Chapter 5 of my book, I present statistical evidence that-even after controlling for a variety of relevant factors, including the percentage of the population that is Scheduled Caste/Scheduled Tribe, the percentage of forest in a region, the existence of mining operations, literacy rates, etc.-former British provinces have more Naxalite violence today than former princely states.

Many scholars have argued that British direct rule correlates with the Naxalite movement, as well as a variety of other adverse political and economic outcomes. This is especially true in areas that came under landlord (zamindari, or in central-eastern India, malguzari) rule. Paul Brass makes this argument, noting that the early Maoist movement in Bihar was organized against local landlords. ${ }^{14}$ The economists Abhijit Banerjee and Lakshmi Iyer find that landlord districts tend to underperform non-landlord districts in India today in terms of investments, agricultural yields, and health and educational outcomes. ${ }^{15}$ Joseph Flavian Gomes contends that historical property rights institutions derived from colonial rule are a key component in the political economy of the Naxalite movement. ${ }^{16}$ Considering all this, I do not think that Dr Sundar's attacks on the comparative and interdisciplinary approach of my article are valid-especially from within the field of political science-nor do I think she has engaged in the voluminous literature on British and princely rule and the Naxalite insurgency produced by my discipline.

\footnotetext{
${ }^{14}$ Brass, P.R. (1994). The Politics of India Since Independence, $2^{\text {nd }}$ edition, Cambridge University Press, Cambridge, p. 327.

${ }^{15}$ Banerjee, A., and Iyer, L. (2005). History, Institutions, and Economic Performance: The Legacy of Colonial Land Tenure Systems in India, American Economic Review 95:4, pp. $1190-1213$.

${ }^{16}$ Gomes, J.F. (2015). The Political Economy of the Maoist Conflict in India: An Empirical Analysis, World Development 68, pp. 96-123.
} 
As the homepage of the $M A S$ website states, the journal 'welcomes articles which deploy inter-disciplinary and comparative research methods'. This solicitation is part of why I chose to submit my article to $M A S$; I thought that publishing my work in this venue would promote productive interdisciplinary scholarship, especially by providing a view from political science. By my count, over the past two years-a period covering the publication of 94 articles-there have only been seven political scientists published in $M A S$, and only two political scientists published who study India. I can say anecdotally that none of my fellow junior colleagues who study India seem interested in sending their work to $M A S$, preferring instead to publish in our own disciplinary journals. I cannot imagine, after reading Dr Sundar's letter, that many of them are regretting their decision. This, however, would be the wrong lesson to learn from this episode. I hope my junior colleagues will consider sending their work to $M A S$ because interdisciplinary engagement is too important to be impeded by fights over academic 'turf'. And I believe that most $M A S$ readers are open to different perspectives. As Frederick Cooper suggests, 'The remedy for these difficulties of interdisciplinary work, however, is not disciplinarity but discipline: a more thorough and critical engagement with other fields, a more rigorous and wider reading of social theory that both reconfigures and deepens methodological understandings. ${ }^{17}$

Ajay Verghese 26 April 2017 Riverside, California

${ }^{17}$ Cooper, F. (2005). Colonialism in Question: Theory, Knowledge, History, University of California Press, Berkeley, p. 6. 